\title{
Emerging Role of High Mobility Group Box-1 in Thrombosis-Related Diseases
}

\author{
Han Wu Ran Li Li-Gang Pei Zhong-Hai Wei Li-Na Kang Lian Wang \\ Jun Xie Biao Xu
}

Department of Cardiology, Drum Tower Hospital, Nanjing University Medical School, Nanjing, China

\author{
Key Words \\ Coronary artery disease - Disseminated intravascular coagulation - HMGB-1 - Peripheral \\ arterial disease $\cdot$ Stroke $\cdot$ Venous thrombosis
}

\begin{abstract}
High mobility group box-1 (HMGB-1), a typical damage-associated molecular pattern protein released from various cells, was first identified in 1973. It is usually stored in the nuclei of cells. Several modifications of HMGB-1 promote its translocation to the cytosol, and it is actively or passively released from cells. When outside of the cells, HMGB-1is crucial in inflammation. It exerts its biological functions via interaction with its receptors, including receptor for advanced glycation end products (RAGE) and Toll-like receptor 4(TLR4). A large number of studies showed a close link between inflammation and thrombosis. This review demonstrated the increased expression of HMGB-1 in thrombosis-related diseases, including coronary artery disease, stroke, peripheral arterial disease, disseminated intravascular coagulation, and venous thrombosis. Besides, it summarized the current understanding of the emerging link between HMGB-1 and thrombosis from three aspects: platelet, NETs, and coagulation and fibrinolysis factors. Finally, it explored the possible therapeutic strategies targeting HMGB-1 for treating thrombosis-related diseases.
\end{abstract}

\section{Structure of HMGB-1}

A detailed overview of HMGB-1 has been extensively reviewed elsewhere [1]. Briefly, HMGB-1, a nonhistone protein, is constitutively present in nearly all types of cells. It is an evolutionarily conserved 30-kDa DNA-binding protein in the nucleus, including two internal repeats of positively charged domains (A box and B box) in the N-terminus and a continuous stretch of negatively charged residue in the C-terminus. HMGB-1 A box is usually considered as an antagonist of full-length HMGB-1 because it binds to the same site. Thus, HMGB-1 A box suppresses inflammatory response by competing with HMGB-1. However, HMGB-1 B box facilitates the affinity of HMGB-1 and its receptors, leading to inflammation (Fig. 1A).

H. Wu and R. Li contributed equally to this work. 


\section{Redox states of HMGB-1}

HMGB-1 is classified into three subtypes according to the modification of cysteine residues. It exerts its various effects via different isoforms [2]. HMGB-1 contains three critical cysteine residues (C23, C45, and C106), which are modified by redox signaling to form three HMGB-1 isoforms (all-thiol HMGB1, disulfide HMGB-1, and oxidized HMGB-1) [3, 4]. When all the cysteine residues are fully reduced, the HMGB-1 is termed as all-thiol HMGB-1 (Fig. 1B). All-thiol HMGB-1 may promote leukocyte recruitment via binding to CXCL12 and CXCR4 [5, $6]$, suggesting that reduced forms of three cysteine residues contribute to its chemotactic activity. A recent study demonstrated that plateletderived HMGB-1 promoted the recruitment of monocytes, with potential implications in thrombosis and inflammation [7]. However, two cysteine residues are oxidized to form a disulfide bond between $\mathrm{C} 23$ and C45, which is termed as disulfide HMGB-1 (Fig. 1C). Disulfide HMGB-1 could induce nuclear factor-kappaB (NF- $\mathrm{KB})$ translocation and secretion of inflammatory factors via Toll-like receptor (TLR) 4 in activated immune cells $[3,8,9]$. However, mutations of C23 or C45 could abolish HMGB-1 cytokine activity [2]. In line with these findings, another report indicated that disulfide HMGB-1 caused bladder pain through TLR4 activation [10]. Besides, it stimulated smooth muscle cells and macrophages to produce inflammatory cytokines via TLR4 $[11,12]$ Recently, Frank et al. found that disulfide HMGB-1 potentiated neuroinflammatory response in vivo. However, all-thiol HMGB-1 failed to promote the microglial proinflammatory response to lipopolysaccharide (LPS) [13]. Consistent with the findings of others, a recent study showed that oxidative stress promoted the secretion of HMGB-1 and other proinflammatory factors, wherein HMGB-1 was partially oxidized $[14,15]$. In a venous thrombosis model, disulfide HMGB-1, released from platelets and neutrophils, could promote neutrophil recruitment and neutrophil extracellular trap (NET) formation, and contributed to thrombosis via redundant pattern recognition receptors [16]. Thus, disulfide HMGB-1 might promote thrombosis via inflammation. The third form of HMGB-1 is oxidized HMGB-1, which is characterized by three fully oxidized cysteine residues (Fig. 1D). In contrast to all-thiol HMGB-1 and disulfide HMGB-1, oxidized HMGB-1 has no biological functions such as chemokine and proinflammatory activities $[9,17]$.

\section{HMGB-1-mediated signaling pathways}

HMGB-1 fundamentally resides in the nucleus under normal circumstances, stabilizing nucleosomes and facilitating gene transcription [18]. However, when it is hyperacetylated under some conditions, HMGB-1 translocates from the nucleus to the cytosol and is subsequently released from the stressed or activated cells [19]. Early reports demonstrated 


\section{Cellular Physiology \begin{tabular}{l|l|l} 
and BOI: 10.1159/000490818 & $\begin{array}{l}\text { ( ) 2018 The Author(s). Published by S. Karger AG, Basel } \\
\text { www.karger.com/cpb }\end{array}$
\end{tabular}

that HMGB-1 could be passively or actively released outside. On the one hand, HMGB1 is passively diffused from various cells to the extracellular space during cellular necrosis or damage [20]. On the other hand, HMGB- 1 is actively released outside of macrophages, monocytes, and dendritic cells (DCs) when the cells are activated [1].

Once in the extracellular space, HMGB-1 exerts its biological functions via interaction with its receptors, including receptor for advanced glycation end products (RAGE) [21, 22], TLR2 [2326], TLR4 [27-30], and TLR9 [31]. The interaction between HMGB-1 and its receptors has been shown to induce cell adhesion [32], permeability [33, 34], chemotaxis [35], inflammation [36-38], autophagy [39-41], apoptosis [42-44], thrombosis [16, 45, 46], angiogenesis

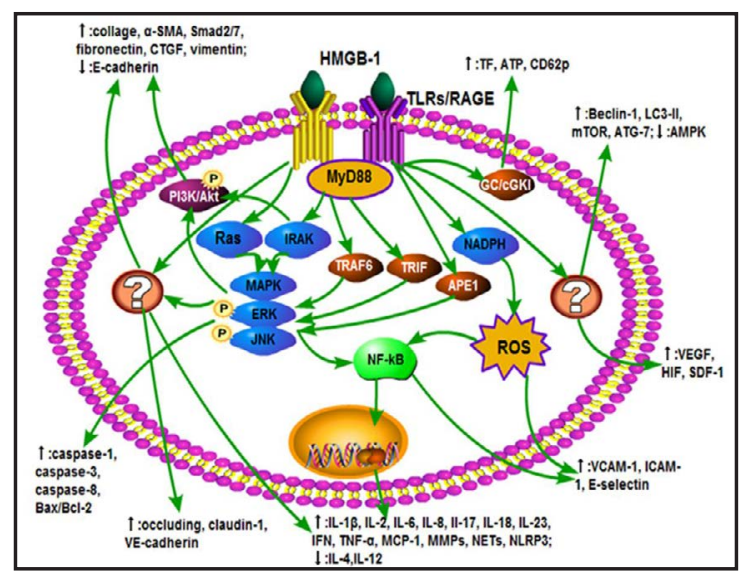

Fig. 2. Signaling pathways of HMGB-1. The interaction between HMGB-1 and its receptors induced the activation of downstream signaling pathways during cell adhesion, permeability, chemotaxis, inflammation, immunization, autophagy, apoptosis, thrombosis, angiogenesis, fibrosis, and epithelial-mesenchymal transition (EMT). $[47,48]$, fibrosis $[49,50]$, and epithelialmesenchymal transition (EMT) [51,52]. Although the exact mechanisms involved in the progression still remain unclear, myeloid differentiation factor 88 (MyD88)-mediated pathways have been the most studied.

Recombinant HMGB-1 directly promoted the expression of MyD88, NF- $\kappa \mathrm{B}$, tumor necrosis factor (TNF)- $\alpha$, and interleukin (IL)- $1 \beta$ in mouse primary cortical neurons, suggesting that HMGB-1 could induce proinflammatory factors via the MyD88-dependent pathway [53]. The deficiency of MyD88 inhibited HMGB-1-induced TNF- $\alpha$ release in macrophages [12]. However, an in vivo study demonstrated that MyD88-deficient mice exhibited significantly lower IL-6 levels after cold ischemia-reperfusion injury [54]. Several receptors have indicated the involvement of MyD88 in the HMGB-1-mediated pathway. HMGB-1 has been shown to promote antineutrophil cytoplasmic antibody-antigen translocation in neutrophils, which was attenuated by blocking TLR4, RAGE, MyD88, and NF- $\kappa B$ [55] . Combined deficiency of TLR2/TLR4, or of MyD88 alone, attenuated HMGB-1-induced expression of MMP-3 and MMP-13 in chondrocytes [56]. In line with these findings, another study demonstrated that HMGB-1 treatment increased the levels of proinflammatory markers in the lungs of wildtype mice but not in TLR4-knockout mice [57]. An in vitro study demonstrated that blocking TLR4 or MyD88 inhibited HMGB-1-induced proinflammatory cytokine production in mouse tracheal epithelial cells [58]. Furthermore, Das et al. found that the interaction of HMGB1 and TLR5 initiated NF- $\mathrm{KB}$ activation via MyD88, resulting in proinflammatory cytokine production in vivo [59]. These findings indicated that HMGB-1 exhibited its proinflammatory effect via the MyD88-dependent pathway by binding to its receptors. As shown in Fig. 2, dozens of other molecules have also been implicated in HMGB-1-related signaling pathways.

\section{Expression of HMGB-1 in coronary artery disease, stroke, peripheral arterial disease, disseminated intravascular coagulation, and venous thrombosis}

A large number of reports in the last decade demonstrated the role of HMGB-1 in thrombosis-related diseases (Table 1). HMGB-1 has been considered as a critical mediator in cardiovascular diseases $[1,60]$. Several investigations showed that serum HMGB-1 was higher in patients with acute coronary syndrome [61-65]. In line with these studies, the upregulated HMGB-1 level and thrombosis were found in patients with plaque rupture compared with volunteers [66]. Moreover, immunofluorescence staining showed abundant 
expression of HMGB-1 in platelet-rich human coronary artery thrombi $[46,67]$. Furthermore, plasma HMGB-1 level in coronary heart disease was significantly higher in patients with chest pain than in those with no plaque [66, 68-70], suggesting the value of HMGB-1 in the increased risk of coronary heart atherosclerosis $[68,69,71]$. Similar results were also observed in animal experiments showing that apoE-/- mice exhibited increased expression of HMGB-1 in the aortic sinus [22, 72]. The occurrence of postprocedural myocardial injury was higher in the patients with elevated HMGB-1 levels [73]. However, HMGB-1 expression in circulating platelets was not associated with outcomes in symptomatic coronary artery disease [74]. Thus, serum / plasma HMGB-1 was considered as a potential and independent predictor of cardiovascular mortality in patients with acute coronary syndrome $[61,62,64$, 75].

A number of investigations indicated the link between HMGB-1 and ischemic stroke. Several studies showed that plasma HMGB-1 level was elevated following ischemic stroke for months [76, 77] and was correlated with the severity of stroke [76]. Furthermore, a recent study indicated that elevated HMGB-1 level was associated with poor functional outcome in ischemic stroke [78]. In animal experiments, ischemia mice/rats exhibited a higher expression of HMGB-1 in serum [79-81], plasma [82-84], cerebrospinal fluid (CSF) $[85,86]$, and brain tissue $[21,84,87-91]$.

Accumulating data revealed a correlation between HMGB-1 and peripheral arterial disease (PAD). An earlier report demonstrated that the concentration of plasma HMGB1 increased in patients with PAD than in healthy controls [92]. This notion was strongly supported by a recent study showing higher serum HMGB-1 levels in patients with type 2 diabetes affected by PAD [93]. Furthermore, the expression of HMGB-1 increased in diabetic foot atherogenesis and arteriosclerosis obliterans [94, 95].

Disseminated intravascular coagulation (DIC) is a clinical syndrome characterized by the activation of the coagulation system, and increasing evidence has supported the role

Table 1. Expression of HMGB-1 in thrombosis-related diseases

\begin{tabular}{|c|c|c|c|c|}
\hline Disease & Sample & $\begin{array}{l}\text { Detection } \\
\text { method }\end{array}$ & Regulatory role & Ref. \\
\hline CAD & Serum & ELISA & Increased preoperative HMGB-1 predicted myocardial injury post-PCI & [73] \\
\hline CAD & Serum & ELISA & HMGB-1 levels were markedly increased in patients with CAD and were associated with plaque burden & {$[66,69-71]$} \\
\hline ACS & Serum & WB & Serum HMGB-1 levels were elevated in patients with myocardial ischemia & [65] \\
\hline AMI & Serum/Plasma & ELISA & $\begin{array}{l}\text { HMGB- } 1 \text { levels were higher in patients with AMI and were associated with adverse clinical outcomes in } \\
\text { the postinfarction healing process }\end{array}$ & {$[61-64,75]$} \\
\hline AMI & $\begin{array}{l}\text { Thrombi } \\
\text { tissue }\end{array}$ & IHC & Extracellular HMGB-1 was closely localized with platelets in the coronary thrombi & {$[46,67]$} \\
\hline Chest pain & Plasma & ELISA & $\begin{array}{l}\text { Increased plasma HMGB-1 levels might be associated with increased risks of coronary atherosclerosis } \\
\text { in young patients with chest pain }\end{array}$ & [68] \\
\hline AS model & Aortic tissue & IHC & $\begin{array}{l}\text { HMGB-1 was expressed within the aortic sinus of apoE-/- mice and restricted to cells within the } \\
\text { intima }\end{array}$ & {$[22,72]$} \\
\hline $\begin{array}{l}\text { Ischemic } \\
\text { stroke }\end{array}$ & ELISA & Plasma & HMGB-1 levels were higher in patients with ischemic stroke than in controls & {$[76,77]$} \\
\hline $\begin{array}{l}\text { Ischemic } \\
\text { stroke }\end{array}$ & ELISA & Serum & Serum HMGB- 1 levels increased in patients with ischemic stroke relative to healthy controls & [78] \\
\hline MCAO model & ELISA/WB & $\begin{array}{l}\text { Serum/ } \\
\text { Plasma }\end{array}$ & HMGB-1 levels were significantly increased in MCAO models & {$[79-84,90]$} \\
\hline MCAO model & WB & CSF & Expression of HMGB-1 in CSF was elevated in MCAO models & {$[85,86,90]$} \\
\hline MCAOmodel & $\mathrm{WB} / \mathrm{IHC}$ & Brain tissue & HMGB-1 translocated and was released into the extracellular space in postischemic brain & $\begin{array}{l}{[21,84,87-} \\
90]\end{array}$ \\
\hline PAD & ELISA & Plasma & Concentration of HMGB- 1 increased in patients with PAD & [92] \\
\hline PAD & ELISA & Serum & HMGB-1 levels were higher in patients with T2D accompanied by PAD & [93] \\
\hline PAD & $\mathrm{IHC}$ & Artery tissue & Expression of HMGB-1 increased in patients with diabetes accompanied by PAD & [94] \\
\hline DIC & ELISA & Plasma & Plasma HMGB-1 levels were correlated with DIC & {$[98,177]$} \\
\hline DIC & ELISA & Serum/Plasma & HMGB-1 levels were higher in septic patients with DIC than in septic patients without DIC & $\begin{array}{l}{[97,98,} \\
177]\end{array}$ \\
\hline DIC & ELISA & Serum & $\begin{array}{l}\text { Patients with higher HMGB-1 levels developed DIC in hematological malignancies complicated with } \\
\text { SIRS }\end{array}$ & [99] \\
\hline DIC & ELISA & Serum & Platelet activation markers were correlated with serum HMGB-1 levels in DIC & [100] \\
\hline VT & IF & $\begin{array}{l}\text { Inferior vena } \\
\text { cava }\end{array}$ & HMGB-1 was expressed in inferior vena cava & [16] \\
\hline CVST & WB & Brain tissue & Expression of HMGB-1 protein increased in CVST & [101] \\
\hline
\end{tabular}


of HMGB-1 in DIC [96-98]. Serum HMGB-1 level was higher in patients with DIC than in those without DIC [96-98]. Plasma HMGB-1 level was demonstrated as an independent factor in the diagnosis of DIC with leukemia [96]. Moreover, patients with higher HMGB-1 in hematological malignancies might be complicated by DIC [99]. HMGB-1 was correlated with platelet activation markers in patients with DIC accompanied by hematologic malignancy [100]. Besides, patients with organ failure and nonsurvivors exhibited the highest HMGB-1 levels among patients with DIC [98]. This suggested that HMGB-1 level increased and was associated with organ failure in DIC $[96,98]$.

Two recent studies reported the role of HMGB-1 in venous thrombosis. The expression of HMGB-1 in brain tissue was higher in a cerebral venous sinus thrombosis (CVST) model compared with control animals [101]. Also, recombinant human soluble thrombomodulin protected against CVST via the inhibition of HMGB-1 [101]. Further, platelet-derived disulfide HMGB-1 contributed to venous thrombosis as a central mediator of the sterile inflammatory process [16].

\section{Mechanisms of HMGB-1-mediated thrombosis}

Numerous experimental and clinical studies have shed light on the role of HMGB-1 in thrombosis-related diseases. However, the underlying molecular mechanisms have not been fully elucidated. The present review aimed to discuss the mechanisms from three aspects: platelet, NETs, and coagulation and fibrinolysis factors.

\section{HMGB-1 and platelets}

Platelets, which are anucleated cells in blood, are believed to be centrally involved in thrombosis progression. Circulating platelets migrate to the sites and initiate a set of thrombosis-related processes upon vascular injury. The platelets aggregated and released granules through the receptor recognition of exposed subendothelium. These granules promoted the activation of platelets via a positive feedback and contributed to thrombosis formation.

Accumulating data suggested that inflammation induced thrombosis via the activation of platelets. Emerging studies in recent years have shed light on the functions of platelets induced by HMGB-1. In 2000, Rouhiainen et al. detected the expression of HMGB-1 in human platelets using Western blot and reverse transcription-polymerase chain reaction [102]. Moreover, HMGB-1 exhibited cytoplasmic localization in resting platelets and translocated into the surface of active platelets. Since then, a number of studies provided a close link between HMGB-1 and activation of platelets. Consistent with earlier reports, HMGB-1 was rarely detected in the plasma and was mainly an intracellular protein [103]. However, thrombin, collagen, C-reactive protein, or adenosine diphosphate induced translocation of HMGB-1 from the cytoplasm to the supernatant in platelets [104-106]. Interestingly, thrombin or collagen did not change the exosome secretion of purified platelets. However, cytoplasmic HMGB-1 could be released from thrombin- or collagen-induced platelets under conditions of high extracellular calcium, suggesting that extracellular calcium mediated thrombin/collagen-induced expression of HMGB-1 in platelets [104]. Thus, these findings indicated extracellular calcium-dependent HMGB-1 secretion in active platelets.

Once released outside of platelets, HMGB-1 could exhibit its effects on platelets. In a DIC model, HMGB-1-treated mice exhibited higher platelet concentrations compared with vehicle-treated mice [107]. Increasing evidence in the last decade suggested that HMGB-1 could recognize its receptor on platelets, contributing to platelet aggregation and secretion $[46,103]$. Recently, HMGB-1 was shown to promote platelet activation, granule secretion, adhesion, and spreading in vitro. In animal experiments, platelet-specific deficiency of HMGB-1 induced increased bleeding times, reduced thrombus formation, and reduced 
platelet aggregation [45]. Consistent with this study, another investigation indicated that HMGB-1 accelerated thrombin-induced coagulation in vivo [107], suggesting that HMGB1 promoted coagulation via platelet activation. Many receptors exist for HMGB-1, the important ones being RAGE, TLR2, TLR4, and TLR9. Zhang et al. demonstrated that LPSactivated platelet aggregation required the TLR4 pathway [108]. The deletion of TLR4 gene resulted in the reduced expression of P-selectin in platelets and reduced aggregation ability on thrombin stimulation, indicating the role of TLR4 in platelet activation $[109,110]$. Moreover, the enhanced expression of TLR4 on platelets in patients with acute coronary syndrome revealed the possible role of TLR4 in platelet aggregation [111]. Consistent with these studies, two recent investigations showed that the HMGB-1/TLR4-mediated signaling pathway contributed to platelet activation and thrombosis $[45,103]$. Besides, they found that HMGB-1-induced platelet aggregation was attenuated in MyD88-deficient platelets, suggesting that the TLR4/MyD88 pathway contributed to HMGB-1-stimulated platelet aggregation [45]. Furthermore, extracellular regulated protein kinase (ERK) and guanylate cyclase (GC)/cyclic guanosine monophosphate (cGMP)/cGMP-dependent protein kinase I (cGKI) were found to be the downstream signaling pathways of TLR4 in HMGB-1-induced platelets [45]. This was in line with a previous report indicating that the TLR/MyD88- and cGMP-dependent protein kinase pathway collectively contributed to LPS-induced platelet activation [108].

Another well-characterized signaling mechanism by which TLR4 exhibits its effect on platelet is NF- $\kappa B$-mediated signaling pathway. Yang recently found that HMGB-1 triggered $\mathrm{NF}-\kappa \mathrm{B}$ activation and regulated the expression of cGMP in platelets. Moreover, the inhibition of NF- $\kappa \mathrm{B}$ impaired HMGB-1-induced platelet activation and reduced I $\kappa \mathrm{B} \alpha$ phosphorylation [103]. It meant that NF- $\kappa \mathrm{B} / \mathrm{I} \kappa \mathrm{B} \alpha$ was involved in HMGB-1-induced platelet activation [103, 112]. Furthermore, the inhibition of NF- $\kappa B$ reversed the decreased level of $c G M P$, indicating the role of cGMP in HMGB-1-induced platelet activation. These findings were consistent

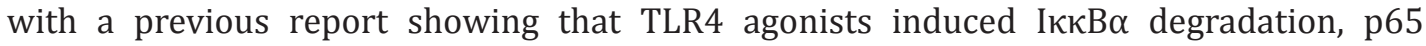
phosphorylation, and platelet aggregation [112]. Thus, HMGB-1 might induce the activation of platelets via the TLR4/NF- $\kappa \mathrm{B} / \mathrm{I} \kappa \mathrm{B} \alpha / \mathrm{cGMP}$ pathway.

Although the aforementioned evidence indicated that the TLR4-dependent signaling pathway (but not TLR2) mediated HMGB-1-induced platelet activation, divergent findings from other groups need to be taken into consideration. Ward et al. found that agonists of TLR4 were unable to modulate platelet activation. The discrepancy between these results might be due to different agonists with different dosages and durations [113].

Besides TLR4, engagement of platelet TLR9 by carboxy protein promoted platelet hyperreactivity and thrombosis [114]. However, whether HMGB-1 could induce the activation of platelets via TLR9 was still unclear. HMGB-1 could also bind to activated platelets by binding to RAGE and TLR4 [46]. However, whether HMGB/RAGE contributed to platelet activation remains debatable. Two recent studies demonstrated that HMGB-1 could not induce the activation of $\mathrm{RAGE}^{-/-}$platelets $[45,103]$. The different conditions of platelets involved in these experiments and different ways to detect platelet activation might explain the discrepancy among studies.

\section{HMGB-1 and NETs}

Sterile inflammation is a known critical factor in the development of thrombosis. The correlation between HMGB-1 and sterile inflammation was reviewed in 2014 [36]. However, increasing evidence in the last 3 years has supported the involvement of HMGB-1 in sterile inflammation [115-118]. Blockade of extracellular HMGB-1 attenuated inflammation and coagulation abnormalities in traumatic coagulopathy models [119], suggesting that HMGB-1 could promote thrombosis via sterile inflammation. Reduced HMGB-1 on the surface upon activation induced the recruitment of monocytes, and active leukocytes in turn promoted the 


\section{Cellular Physiology Cell Physiol Biochem 2018;47:1319-1337 \\ \begin{tabular}{ll|l} 
and Biochemistry Published online: June 22, 2018 & $\begin{array}{l}\text { C } 2018 \text { The Author(s). Published by S. Karger AG, Basel } \\
\text { www.karger.com/cpb }\end{array}$
\end{tabular} \\ Wu et al.: Hmgb-1 in Thrombosis}

oxidation of HMGB-1, unleashing its prothrombotic activity [16]. Thus, sterile inflammation may be vital in HMGB-1-induced thrombosis.

NETs were produced during infection and created fibrous nets with high concentrations of antimicrobial proteins to trap and kill microbes in the extracellular environment. When the neutrophils were activated, granular enzymes such as neutrophil elastase translocated to the nucleus. Active enzymes promoted chromatin decondensation and released unwound chromatins outside the cells. Then, NETs were released from lysed cells, including extracellular DNA and histones [120,121]. An accumulating body of evidence suggested that NETs contributed to thromboses such as venous thrombosis [122-124], DIC [125], and coronary thrombosis [126-129].

NETs may provide a reaction interface for von Willebrand factor ( $\mathrm{vWF}$ ), which facilitates the adhesion of platelets via platelet-surface receptor complex, contributing to platelet activation [130]. In addition to NET-platelet interactions, histones and neutrophil proteases in NETs also contributed to platelet activation. Semeraro and colleagues demonstrated that extracellular histones promoted the activation of platelets via TLR2 and TLR4 [131]. Besides, human neutrophil elastase promoted platelet aggregation via the activation of platelet receptors [132]. Thus, NETs promoted platelet adhesion, activation, and aggregation, contributing to thrombus formation when perfused with blood. In addition to white thrombus, NETs induced the formation of red thrombus via activating coagulation factors and trapping red blood cells and fibrin. Elevated NETs in patients with sepsis have been shown to promote the generation of thrombin and fibrin in normal plasma [133]. Gould et al. found that NETs enhanced thrombin generation regardless of platelets [134]. NETs from active neutrophils could bind and stimulate factor XII activation [123]. Another report suggested that serine proteases and extracellular nucleosomes induced tissue factor- and factor XII-dependent coagulation via the proteolytic inactivation of tissue factor pathway inhibitor (TFPI) [135].

In the last few years, much attention has been devoted to assessing the role of HMGB-1 in NET formation, which promoted coagulation and thrombosis formation [106]. Thus, the crosstalk between HMGB-1 and NETs was critical in thrombosis.

Oxidative stress in neutrophils was implicated in NET formation and led to thrombosis under inflammatory conditions. Treatment with $\mathrm{H}_{2} \mathrm{O}_{2}$ promoted the activation of neutrophils and monocytes. However, the stimulatory effects were reversed by catalase, suggesting that HMGB-1 might induce neutrophil activation via oxidative stress [136]. This notion was supported in endothelial progenitor cells, with HMGB-1 serving as a mediator for oxidative stress [15].

Nicotinamide adenine dinucleotide phosphate (NADPH) oxidase, a critical source of reactive oxygen species (ROS) genesis, was involved in the HMGB-1-induced activation of neutrophils $[137,138]$. HMGB-1 exerted its effects on NET genesis via binding to its receptors including TLR2, TLR4, and RAGE, this process was dependent on NADPH oxidase [137]. In line with this study, Fan found that HMGB-1 promoted the activation of neutrophils via the TLR4/NADPH pathway. Furthermore, the TLR4-dependent activation of NADPH oxidase was mediated via the MyD88-(interleukin -1 receptor-associated kinase (IRAK)(p38 mitogen activated protein kinase (p38MAPK)/Akt signaling pathway [139]. In contrast, another report showed that MyD88 did not apparently influence the ability of HMGB-1 for NET generation [106]. One possible explanation for this divergence might be the difference in models.

In addition to NADPH oxidase-dependent ROS genesis, NADPH oxidase-independent ROS generation also contributed to HMGB-1-induced oxidative stress. Active platelets induced by HMGB-1 expressed and released P-selectin, and then P-selectin/P-selectin glycoprotein ligand 1 (PSGL-1) interaction was crucial in oxidative stress in leukocytes [136]. Moreover, HMGB-1 induced activation of neutrophils via the activation of myeloperoxidase [136]. Moreover, blockade of the autophagic flux reverted HMGB-elicited NET generation, suggesting that HMGB-1 might promote NET formation via the activation of autophagy [106]. Thus, these studies collectively suggested that HMGB-1 induced thrombosis via NET formation. 


\section{HMGB-1 and coagulation and fibrinolysis factors}

Tissue factor (TF), also known as coagulation factor III, was found to be involved in inflammation-related thrombosis. Also, HMGB-1 could upregulate the expressions of TF in monocytes [107]. This result was also confirmed by Lv et al., demonstrating that HMGB-1 induced expression and activation of TF in endothelial cells in a concentration- and timedependent manner [140]. Its effect on TF activity induced by HMGB-1 was partly attenuated by three neutralizing antibodies (anti-LTR2, anti-LTR4, and anti-RAGE) and NF- $\kappa \mathrm{B} /$ early growth response 1 (Egr-1) interference, suggesting that TLR2/TLR4/RAGE and NF- $\mathrm{KB}$ / Egr-1 pathway mediated the HMGB-1-induced expression of TF [140]. TF induced blood coagulation cascade via the formation of TF/FVIIa complex, which could be inhibited by TFPI [141]. Thus, TFPI was also detected in this study. It showed that the stimulation of endothelial cells with HMGB-1 did not regulate the expression of TFPI [140], suggesting that TFPI was not involved in the HMGB-1-induced expression of TF. Moreover, HMGB-1 could inhibit the activation of protein C [107], suggesting that the prothrombotic effects of HMGB1 were mediated by increased coagulation factors and decreased anticoagulant factors.

Besides coagulation factors, the correlation between HMGB-1 and fibrinolysis has been indicated in several studies. Recently, Kules and colleagues found that HMGB-1, an endothelial activation marker, was increased in dogs with babesiosis in parallel with elevated soluble urokinase receptor of plasminogen activator (suPAR), suggesting a possible role of HMGB-1 in fibrinolysis [142]. Besides, HMGB-1 has been shown to induce the formation of plasminogen activator inhibitor-1/tissue plasminogen activator (PAI-1/tPA) complexes, suggesting that HMGB-1 might prevent fibrinolysis via increased PAI-tPA complexes in endothelial cells [143]. Collectively, these data provided evidence that coagulation and fibrinolysis factors were involved in HMGB-1-induced thrombosis.

Nitric oxide (NO), especially from endothelial NO synthase (eNOS), has been considered as an important antithrombotic factor [144]. Several studies demonstrated that HMGB-1 could regulate eNOS/NO axis in endothelial cells. A previous clinical study illustrated that the serum levels of HMGB-1 were correlated negatively with NO levels in patients with obstructive sleep apnea syndrome [145]. Moreover, cholesterol crystal markedly induced the expression of HMGB-1 and downregulated eNOS activity in coronary endothelial cells [146], and treatment with recombinant HMGB-1 directly induced endothelial dysfunction in vitro [146]. Recently, Tang et al. found that miR-126 upregulated eNOS activity by targeting HMGB-1, suggesting that HMGB-1 suppressed the activity of eNOS in endothelial cells [147]. Another recent in vitro study revealed that uric acid inhibited the expression of eNOS and NO production in endothelial cells and increased extracellular HMGB-1 secretion in parallel with elevated expression of RAGE, demonstrating that HMGB-1 could promote endothelial dysfunction via RAGE [148]. These data suggested the involvement of endothelial cell-derived NO in thrombosis, although the underlying mechanisms are not completely understood.

\section{Therapeutic strategy for HMGB-1}

Given the role of HMGB-1 in thrombosis, several studies have focused on drugs targeting HMGB-1 in thrombosis-related diseases. Although no drugs targeting HMGB-1 were used in clinical practice, some anti-HMGB-1 agents were shown to inhibit the expression of HMGB-1 in ischemic animal models, including glycyrrhizin [90, 149, 150], ethyl pyruvate (EP) [151, 152], tanshinone IIA [153, 154], fluvastatin [155], berberine [156], moclobemide [157], minocycline [158], probenecid [159], portulaca [160], apelin-13 [161], hesperidin [162] and bleacein [163]. Glycyrrhizin, a glycoconjugated triterpene present in licorice root, has been shown to exert protective effects in various diseases via suppressing HMGB-1. Glycyrrhizin administration inhibited HMGB-1 secretion in CSF and serum after stroke, suggesting that glycyrrhizin protected brain ischemic injury partly via the inhibition of HMGB-1 [90]. In line with the findings, Huang et al. found that glycyrrhizin alleviated the aggravation of infarct 
volume in middle cerebral artery occlusion (MCAO) models [150]. Moreover, the infarct volume and release of HMGB-1 from the cerebral cortex into the serum were attenuated by glycyrrhizin in a focal cerebral ischemia-reperfusion model [149]. EP, a lipid derivative of pyruvate, has been considered as another drug targeting HMGB-1 in experimental models. In MCAO models, EP exerted its neuroprotective effect in the postischemic brain via reduced HMGB-1 release [151]. Furthermore, EP markedly reduced aortic sinus atherosclerosis lesions and inhibited the expression of HMGB-1 in apoE-/- mice [152]. Tanshinone IIA was widely used as an antithrombotic drug in China. Recently, tanshinone IIA was shown to reduce infarct size and expression of HMGB-1 in MCAO models [153]. In addition, tanshinone IIA[154] but not IL-23[164] dose-dependently improved the cardiac function and decreased HMGB-1 levels in myocardial injury induced by ischemia-reperfusion . A recent report by Filipek et al showed that oleacein could attenuate the destabilization of carotid plaque in hypertensive patients, suggesting its role in the reduction of the risk of ischemic stroke [163]. Several agents have protective effects on ischemic injury via inhibition of HMGB-1. However, whether HMGB-1-mediated thrombosis was involved in these processes remains poorly understood. Interestingly, several antithrombotic drugs have been shown to block HMGB-1. Nuclear magnetic resonance spectroscopic studies have shown the binding of salicylic acid, an active metabolite of aspirin, to HMGB-1 $[165,166]$. Recently, Goetzel found that aspirin, a classical antiplatelet drug, significantly blocked thrombin- and collagen-induced HMGB1 release in active platelets [104]. Besides, two other antiplatelet drugs (clopidogrel and cilostazol) attenuated the expression of HMGB-1 in septic shock $[167,168]$. Thus, HMGB-1 might serve as a novel target for antiplatelet drugs in thrombotic diseases.

Besides their anticoagulant effects, low-molecular-weight heparins (LMWHs) decreased the expression of HMGB-1 in inflammation [169-171]. Recently, LMWH was shown to suppress the ability of human neutrophils to generate NETs and HMGB-1 [172], indicating that LMWHs might exert their anticoagulant effect by regulating HMGB-mediated NET formation. Besides, 2-0,3-0-desulfated heparin (ODSH) inhibited HMGB-1/RAGEmediated airway inflammation [173]. In macrophages, ODSH blocked HMGB-1 secretion via the inhibition of the activity of acetyltransferase p300 [174]. Thus, HMGB-1 might be a new target for heparin during inflammation and thrombosis.

Similar to heparin, thrombomodulin is another potential drug for DIC. It exhibits its anti-inflammatory effect by regulating HMGB-1. Recombinant soluble thrombomodulin ameliorated cerebral ischemic injury via an HMGB-1 inhibitory mechanism in mice with MCAO [82] and rats with CVST [101]. In a rat septic model, recombinant thrombomodulin suppressed thrombus formation and HMGB-1 levels. Moreover, high-dose thrombomodulin tended to increase the bleeding events [175], suggesting that HMGB-1 was a target for the antithrombotic effect of thrombomodulin. As vascular endothelial cells are critical in the antithrombotic system, Bongoni explored the role of thrombomodulin in HMGB-1-induced endothelial cell activation. He demonstrated that transgenic expression of thrombomodulin inhibited the activation of endothelial cells via increased HMGB-1-induced cleavage [143, 176]. These findings indicated that HMGB-1 might serve as a potential target for anticoagulant drugs.

\section{Conclusion}

HMGB-1 could be actively or passively released from several cells. Once released into the extracellular space, HMGB-1 activated its down signaling via interaction with its receptors. Elevated HMGB-1 levels were associated with clinical prognosis in thrombosis-related diseases. HMGB-1 was critically involved in thrombosis via regulating platelet activation, NETs, coagulation factors, and fibrinolysis factors. Animal experiments indicated that several drugs targeting HMGB-1 exerted protective effects in thrombosis-related diseases. However, the effects of HMGB-1-targeted agents in thrombosis formation in these diseases need to be further explored. 


\begin{tabular}{|c|c|c|}
\hline Cellular Physiology & Cell Physiol Biochem 2018;4 & 17:1319-1337 \\
\hline and Biochemistry & $\begin{array}{l}\text { DoI: } 10.1159 / 000490818 \\
\text { Published online: June 22, } 2018\end{array}$ & $\begin{array}{l}\text { O } 2018 \text { The Author(s). Published by S. Karger AG, Basel } \\
\text { www.kargerc.com/cpp }\end{array}$ \\
\hline
\end{tabular}

\section{Disclosure Statement}

The authors declare to have no competing interests.

\section{Acknowledgements}

The present study was supported by grants from the Natural Science Foundation of China (grant no. 81600285, 81700349), the Funds for Jiangsu Provincial Key Medical Discipline (grant no. ZDXKB2016013), the Key Projects of Science and Technology of Jiangsu Province (grant no. BE2016607), the Funds for Jiangsu Provincial Medical Youth Talent (grant no. QNRC2016033), the Jiangsu Provincial Commission of Health and Family Planning Funds for Young Scholar (grant no. Q201610), the Programs of the Science Foundation in Nanjing (grant nos. ZKX13023, QRX17114, and 201605015), and Fundamental Research Funds for the Central Universities (grant no. 021414380217).

\section{References}

$\checkmark 1$ Cai J, Wen J, Bauer E, Zhong H, Yuan H, Chen AF: The Role of HMGB1 in Cardiovascular Biology: Danger Signals. Antioxid Redox Signal 2015;23:1351-1369.

-2 Yang H, Antoine DJ, Andersson U, Tracey KJ: The many faces of HMGB1: molecular structure-functional activity in inflammation, apoptosis, and chemotaxis. J Leukoc Biol 2013;93:865-873.

3 Lu B, Wang C, Wang M, Li W, Chen F, Tracey KJ, Wang H: Molecular mechanism and therapeutic modulation of high mobility group box 1 release and action: an updated review. Expert Rev Clin Immunol 2014;10:713727.

4 Martinotti S, Patrone M, Ranzato E: Emerging roles for HMGB1 protein in immunity, inflammation, and cancer. Immunotargets Ther 2015;4:101-109.

-5 Schiraldi M, Raucci A, Munoz LM, Livoti E, Celona B, Venereau E, Apuzzo T, De Marchis F, Pedotti M, Bachi A, Thelen M, Varani L, Mellado M, Proudfoot A, Bianchi ME, Uguccioni M: HMGB1 promotes recruitment of inflammatory cells to damaged tissues by forming a complex with CXCL12 and signaling via CXCR4. J Exp Med 2012;209:551-563.

6 Di Maggio S, Milano G, De Marchis F, D’Ambrosio A, Bertolotti M, Palacios BS, Badi I, Sommariva E, Pompilio G, Capogrossi MC, Raucci A: Non-oxidizable HMGB1 induces cardiac fibroblasts migration via CXCR4 in a CXCL12-independent manner and worsens tissue remodeling after myocardial infarction. Biochim Biophys Acta 2017.

7 Vogel S, Rath D, Borst O, Mack A, Loughran P, Lotze MT, Neal MD, Billiar TR, Gawaz M: Platelet-derived highmobility group box 1 promotes recruitment and suppresses apoptosis of monocytes. Biochem Biophys Res Commun 2016;478:143-148.

8 Frank MG, Weber MD, Watkins LR, Maier SF: Stress sounds the alarmin: The role of the danger-associated molecular pattern HMGB1 in stress-induced neuroinflammatory priming. Brain Behav Immun 2015;48:17.

-9 Yang H, Lundback P, Ottosson L, Erlandsson-Harris H, Venereau E, Bianchi ME, Al-Abed Y, Andersson U, Tracey KJ, Antoine DJ: Redox modification of cysteine residues regulates the cytokine activity of high mobility group box-1 (HMGB1). Mol Med 2012;18:250-259.

10 Ma F, Kouzoukas DE, Meyer-Siegler KL, Westlund KN, Hunt DE, Vera PL: Disulfide high mobility group box-1 causes bladder pain through bladder Toll-like receptor 4. BMC Physiol 2017;17:6.

11 Cai J, Yuan H, Wang Q, Yang H, Al-Abed Y, Hua Z, Wang J, Chen D, Wu J, Lu B, Pribis JP, Jiang W, Yang K, Hackam DJ, Tracey KJ, Billiar TR, Chen AF: HMGB1-Driven Inflammation and Intimal Hyperplasia After Arterial Injury Involves Cell-Specific Actions Mediated by TLR4. Arterioscler Thromb Vasc Biol 2015;35:2579-2593. 


\section{Cellular Physiology Cell Physiol Biochem 2018;47:1319-1337

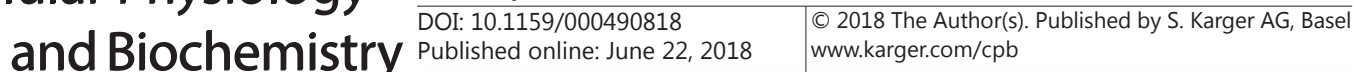

Wu et al.: Hmgb-1 in Thrombosis

12 Kim S, Kim SY, Pribis JP, Lotze M, Mollen KP, Shapiro R, Loughran P, Scott MJ, Billiar TR: Signaling of high mobility group box 1 (HMGB1) through toll-like receptor 4 in macrophages requires CD14. Mol Med 2013;19:88-98.

13 Frank MG, Weber MD, Fonken LK, Hershman SA, Watkins LR, Maier SF: The redox state of the alarmin HMGB1 is a pivotal factor in neuroinflammatory and microglial priming: A role for the NLRP3 inflammasome. Brain Behav Immun 2016;55:215-224.

14 Wu H, Sheng ZQ, Xie J, Li R, Chen L, Li GN, Wang L, Xu B: Reduced HMGB 1-Mediated Pathway and Oxidative Stress in Resveratrol-Treated Diabetic Mice: A Possible Mechanism of Cardioprotection of Resveratrol in Diabetes Mellitus. Oxid Med Cell Longev 2016;2016:9836860.

-15 Wu H, Li R, Wei ZH, Zhang XL, Chen JZ, Dai Q, Xie J, Xu B: Diabetes-Induced Oxidative Stress in Endothelial Progenitor Cells May Be Sustained by a Positive Feedback Loop Involving High Mobility Group Box-1 Oxid Med Cell Longev 2016;2016:1943918.

16 Stark K, Philippi V, Stockhausen S, Busse J, Antonelli A, Miller M, Schubert I, Hoseinpour P, Chandraratne S, von Bruhl ML, Gaertner F, Lorenz M, Agresti A, Coletti R, Antoine DJ, Heermann R, Jung K, Reese S, Laitinen I, Schwaiger M, Walch A, Sperandio M, Nawroth PP, Reinhardt C, Jackel S, Bianchi ME, Massberg S: Disulfide HMGB1 derived from platelets coordinates venous thrombosis in mice. Blood 2016;128:2435-2449.

17 Venereau E, Casalgrandi M, Schiraldi M, Antoine DJ, Cattaneo A, De Marchis F, Liu J, Antonelli A, Preti A, Raeli L, Shams SS, Yang H, Varani L, Andersson U, Tracey KJ, Bachi A, Uguccioni M, Bianchi ME: Mutually exclusive redox forms of HMGB1 promote cell recruitment or proinflammatory cytokine release. J Exp Med 2012;209:1519-1528.

18 Lotze MT, Tracey KJ: High-mobility group box 1 protein (HMGB1): nuclear weapon in the immune arsenal. Nat Rev Immunol 2005;5:331-342.

19 Walko TD, 3rd, Di Caro V, Piganelli J, Billiar TR, Clark RS, Aneja RK: Poly(ADP-ribose) polymerase 1-sirtuin 1 functional interplay regulates LPS-mediated high mobility group box 1 secretion. Mol Med 2015;20:612624.

20 Scaffidi P, Misteli T, Bianchi ME: Release of chromatin protein HMGB1 by necrotic cells triggers inflammation. Nature 2002;418:191-195.

21 Harada S, Matsuura W, Liu K, Nishibori M, Tokuyama S: Possible involvement of the HMGB1/RAGE signaling mechanism in the induction of central post-stroke pain induced by acute global cerebral ischemia. Brain Res 2016;1646:433-440.

-22 Soro-Paavonen A, Watson AM, Li J, Paavonen K, Koitka A, Calkin AC, Barit D, Coughlan MT, Drew BG, Lancaster GI, Thomas M, Forbes JM, Nawroth PP, Bierhaus A, Cooper ME, Jandeleit-Dahm KA: Receptor for advanced glycation end products (RAGE) deficiency attenuates the development of atherosclerosis in diabetes. Diabetes 2008;57:2461-2469.

23 Herzog C, Lorenz A, Gillmann HJ, Chowdhury A, Larmann J, Harendza T, Echtermeyer F, Muller M, Schmitz M, Stypmann J, Seidler DG, Damm M, Stehr SN, Koch T, Wollert KC, Conway EM, Theilmeier G: Thrombomodulin's lectin-like domain reduces myocardial damage by interfering with HMGB1-mediated TLR2 signalling. Cardiovasc Res 2014;101:400-410.

24 Singh B, Biswas I, Bhagat S, Surya Kumari S, Khan GA: HMGB1 facilitates hypoxia-induced vWF upregulation through TLR2-MYD88-SP1 pathway. Eur J Immunol 2016;46:2388-2400.

-25 Feng XJ, Wu C, Yang GF, Liu QJ, Liu JX, Hao J, Xing LL, Yang M, Liu SX: TLR2 Plays a Critical Role in HMGB1Induced Glomeruli Cell Proliferation Through the FoxO1 Signaling Pathway in Lupus Nephritis. J Interferon Cytokine Res 2016;36:258-266.

-26 He Z, Shotorbani SS, Jiao Z, Su Z, Tong J, Liu Y, Shen P, Ma J, Gao J, Wang T, Xia S, Shao Q Wang S, Xu H: HMGB1 promotes the differentiation of Th17 via up-regulating TLR2 and IL-23 of CD14+ monocytes from patients with rheumatoid arthritis. Scand J Immunol 2012;76:483-490.

27 Yao H, Hu C, Yin L, Tao X, Xu L, Qi Y, Han X, Xu Y, Zhao Y, Wang C, Peng J: Dioscin reduces lipopolysaccharideinduced inflammatory liver injury via regulating TLR4/MyD88 signal pathway. Int Immunopharmacol 2016;36:132-141.

28 Zhao H, Zheng Q Hu X, Shen H, Li F: Betulin attenuates kidney injury in septic rats through inhibiting TLR4/NF-kappaB signaling pathway. Life Sci 2016;144:185-193.

29 Chen CB, Liu LS, Zhou J, Wang XP, Han M, Jiao XY, He XS, Yuan XP: Up-Regulation of HMGB1 Exacerbates Renal Ischemia-Reperfusion Injury by Stimulating Inflammatory and Immune Responses through the TLR4 Signaling Pathway in Mice. Cell Physiol Biochem 2017;41:2447-2460. 


\section{Cellular Physiology Cell Physiol Biochem 2018;47:1319-1337 \begin{tabular}{l|l} 
DOI: 10.1159/000490818 & and Biochemistry \\
Published online: June 22, 2018 & $\begin{array}{l}\text { O 2018 The Author(s). Published by S. Karger AG, Basel } \\
\text { www.karger.com/cpb }\end{array}$
\end{tabular}}

Wu et al.: Hmgb-1 in Thrombosis

30 Yang WS, Han NJ, Kim JJ, Lee MJ, Park SK: TNF-alpha Activates High-Mobility Group Box 1 - Toll-Like Receptor 4 Signaling Pathway in Human Aortic Endothelial Cells. Cell Physiol Biochem 2016;38:21392151.

-31 Sumiyoshi M, Satomi J, Kitazato KT, Yagi K, Shimada K, Kurashiki Y, Korai M, Miyamoto T, Suzue R, Kuwayama K, Nagahiro S: PPARgamma-Dependent and -Independent Inhibition of the HMGB1/TLR9 Pathway by Eicosapentaenoic Acid Attenuates Ischemic Brain Damage in Ovariectomized Rats. J Stroke Cerebrovasc Dis 2015;24:1187-1195.

-32 Hassanian SM, Dinarvand P, Rezaie AR: Adenosine regulates the proinflammatory signaling function of thrombin in endothelial cells. J Cell Physiol 2014;229:1292-1300.

33 Mohammad G, Siddiquei MM, Othman A, Al-Shabrawey M, Abu El-Asrar AM: High-mobility group box-1 protein activates inflammatory signaling pathway components and disrupts retinal vascular-barrier in the diabetic retina. Exp Eye Res 2013;107:101-109.

34 Krysko DV, Vanden Berghe T, D’Herde K, Vandenabeele P: Apoptosis and necrosis: detection, discrimination and phagocytosis. Methods 2008;44:205-221.

-35 Xie HL, Zhang Y, Huang YZ, Li S, Wu CG, Jiao XF, Tan MY, Huang YC, Deng L: Regulation of high mobility group box 1 and hypoxia in the migration of mesenchymal stem cells. Cell Biol Int 2014;38:892-897.

-36 Tsung A, Tohme S, Billiar TR: High-mobility group box-1 in sterile inflammation. J Intern Med 2014;276:425-443.

-37 Zhu S, Li W, Ward MF, Sama AE, Wang H: High mobility group box 1 protein as a potential drug target for infection- and injury-elicited inflammation. Inflamm Allergy Drug Targets 2010;9:60-72.

-38 Chaochao Q, Lou G, Yang Y, Liu Y, Hu Y, Min Z, Chen P, He J, Chen Z: Macrophage Inflammatory Protein-2 in High Mobility Group Box 1 Secretion of Macrophage Cells Exposed to Lipopolysaccharide. Cell Physiol Biochem 2017;42:913-928.

-39 Tang D, Kang R, Livesey KM, Cheh CW, Farkas A, Loughran P, Hoppe G, Bianchi ME, Tracey KJ, Zeh HJ, 3rd, Lotze MT: Endogenous HMGB1 regulates autophagy. J Cell Biol 2010;190:881-892.

40 Kang R, Livesey KM, Zeh HJ, 3rd, Lotze MT, Tang D: HMGB1 as an autophagy sensor in oxidative stress. Autophagy 2011;7:904-906.

41 Kang R, Livesey KM, Zeh HJ, Loze MT, Tang D: HMGB1: a novel Beclin 1-binding protein active in autophagy. Autophagy 2010;6:1209-1211.

42 Yao Y, Xu X, Zhang G, Zhang Y, Qian W, Rui T: Role of HMGB1 in doxorubicin-induced myocardial apoptosis and its regulation pathway. Basic Res Cardiol 2012;107:267.

43 Xu H, Yao Y, Su Z, Yang Y, Kao R, Martin CM, Rui T: Endogenous HMGB1 contributes to ischemiareperfusion-induced myocardial apoptosis by potentiating the effect of TNF-\&alpha;/JNK. Am J Physiol Heart Circ Physiol 2011;300:H913-921.

-44 Liu J, Wu P, Wang H, Wang Y, Du Y, Cheng W, Xu Z, Zhou N, Wang L, Yang Z: Necroptosis Induced by AdHGF Activates Endogenous C-Kit+ Cardiac Stem Cells and Promotes Cardiomyocyte Proliferation and Angiogenesis in the Infarcted Aged Heart. Cell Physiol Biochem 2016;40:847-860.

45 Vogel S, Bodenstein R, Chen Q, Feil S, Feil R, Rheinlaender J, Schaffer TE, Bohn E, Frick JS, Borst O, Munzer P, Walker B, Markel J, Csanyi G, Pagano PJ, Loughran P, Jessup ME, Watkins SC, Bullock GC, Sperry JL, Zuckerbraun BS, Billiar TR, Lotze MT, Gawaz M, Neal MD: Platelet-derived HMGB1 is a critical mediator of thrombosis. J Clin Invest 2015;125:4638-4654.

46 Ahrens I, Chen YC, Topcic D, Bode M, Haenel D, Hagemeyer CE, Seeba H, Duerschmied D, Bassler N, Jandeleit-Dahm KA, Sweet MJ, Agrotis A, Bobik A, Peter K: HMGB1 binds to activated platelets via the receptor for advanced glycation end products and is present in platelet rich human coronary artery thrombi. Thromb Haemost 2015;114:994-1003.

47 Park SY, Lee SW, Kim HY, Lee WS, Hong KW, Kim CD: HMGB1 induces angiogenesis in rheumatoid arthritis via HIF-1alpha activation. Eur J Immunol 2015;45:1216-1227.

48 Hayakawa K, Pham LD, Katusic ZS, Arai K, Lo EH: Astrocytic high-mobility group box 1 promotes endothelial progenitor cell-mediated neurovascular remodeling during stroke recovery. Proc Natl Acad Sci U S A 2012;109:7505-7510.

49 Tian S, Zhang L, Tang J, Guo X, Dong K, Chen SY: HMGB1 exacerbates renal tubulointerstitial fibrosis through facilitating M1 macrophage phenotype at the early stage of obstructive injury. Am J Physiol Renal Physiol 2015;308:F69-75. 


\section{Cellular Physiology Cell Physiol Biochem 2018;47:1319-1337

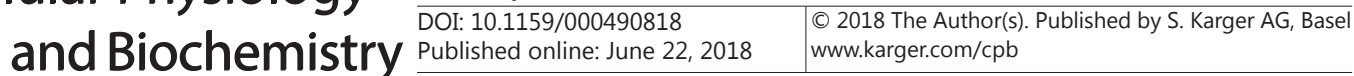

Wu et al.: Hmgb-1 in Thrombosis

-50 Wang WK, Wang B, Lu QH, Zhang W, Qin WD, Liu XJ, Liu XQ An FS, Zhang Y, Zhang MX: Inhibition of highmobility group box 1 improves myocardial fibrosis and dysfunction in diabetic cardiomyopathy. Int J Cardiol 2014;172:202-212.

51 Li LC, Li DL, Xu L, Mo XT, Cui WH, Zhao P, Zhou WC, Gao J, Li J: High-Mobility Group Box 1 Mediates Epithelial-to-Mesenchymal Transition in Pulmonary Fibrosis Involving Transforming Growth Factorbeta1/Smad2/3 Signaling. J Pharmacol Exp Ther 2015;354:302-309.

52 Cui W, Li L, Li D, Mo X, Zhou W, Zhang Z, Xu L, Zhao P, Qi L, Li P, Gao J: Total glycosides of Yupingfeng protects against bleomycin-induced pulmonary fibrosis in rats associated with reduced high mobility group box 1 activation and epithelial-mesenchymal transition. Inflamm Res 2015;64:953-961.

53 Li W, Ling HP, You WC, Ji XJ, Tang Y, Zhao JB, Su XF, Hang CH: Recombinant high-mobility group box 1 protein (HMGB-1) promotes myeloid differentiation primary response protein 88 (Myd88) upregulation in mouse primary cortical neurons. Neurol Sci 2013;34:847-853.

-54 Kaczorowski DJ, Nakao A, Vallabhaneni R, Mollen KP, Sugimoto R, Kohmoto J, Zuckerbraun BS, McCurry KR, Billiar TR: Mechanisms of Toll-like receptor 4 (TLR4)-mediated inflammation after cold ischemia/ reperfusion in the heart. Transplantation 2009;87:1455-1463.

55 Wang C, Wang H, Chang DY, Hao J, Zhao MH, Chen M: High mobility group box 1 contributes to antineutrophil cytoplasmic antibody-induced neutrophils activation through receptor for advanced glycation end products (RAGE) and Toll-like receptor 4. Arthritis Res Ther 2015;17:64.

-56 Liu-Bryan R, Terkeltaub R: Chondrocyte innate immune myeloid differentiation factor 88-dependent signaling drives procatabolic effects of the endogenous Toll-like receptor 2/Toll-like receptor 4 ligands low molecular weight hyaluronan and high mobility group box chromosomal protein 1 in mice. Arthritis Rheum 2010;62:2004-2012.

57 Cheng Y, Wang D, Wang B, Li H, Xiong J, Xu S, Chen Q Tao K, Yang X, Zhu Y, He S: HMGB1 translocation and release mediate cigarette smoke-induced pulmonary inflammation in mice through a TLR4/MyD88dependent signaling pathway. Mol Biol Cell 2016.

58 Cheng Y, Wang D, Wang B, Li H, Xiong J, Xu S, Chen Q Tao K, Yang X, Zhu Y, He S: HMGB1 translocation and release mediate cigarette smoke-induced pulmonary inflammation in mice through a TLR4/MyD88dependent signaling pathway. Mol Biol Cell 2017;28:201-209.

59 Das N, Dewan V, Grace PM, Gunn RJ, Tamura R, Tzarum N, Watkins LR, Wilson IA, Yin H: HMGB1 Activates Proinflammatory Signaling via TLR5 Leading to Allodynia. Cell Rep 2016;17:1128-1140.

60 Chen Q Wang ZY, Chen LY, Hu HY: Roles of High Mobility Group Box 1 in Cardiovascular Calcification. Cell Physiol Biochem 2017;42:427-440.

61 Hashimoto T, Ishii J, Kitagawa F, Yamada S, Hattori K, Okumura M, Naruse H, Motoyama S, Matsui S, Tanaka I, Izawa H, Maruyama I, Nomura M, Ozaki Y: Circulating high-mobility group box 1 and cardiovascular mortality in unstable angina and non-ST-segment elevation myocardial infarction. Atherosclerosis 2012;221:490-495.

62 Andrassy M, Volz HC, Riedle N, Gitsioudis G, Seidel C, Laohachewin D, Zankl AR, Kaya Z, Bierhaus A, Giannitsis E, Katus HA, Korosoglou G: HMGB1 as a predictor of infarct transmurality and functional recovery in patients with myocardial infarction. J Intern Med 2011;270:245-253.

63 Cirillo P, Giallauria F, Pacileo M, Petrillo G, D’Agostino M, Vigorito C, Chiariello M: Increased high mobility group box-1 protein levels are associated with impaired cardiopulmonary and echocardiographic findings after acute myocardial infarction. J Card Fail 2009;15:362-367.

64 Sorensen MV, Pedersen S, Mogelvang R, Skov-Jensen J, Flyvbjerg A: Plasma high-mobility group box 1 levels predict mortality after ST-segment elevation myocardial infarction. JACC Cardiovasc Interv 2011;4:281286.

65 Goldstein RS, Gallowitsch-Puerta M, Yang L, Rosas-Ballina M, Huston JM, Czura CJ, Lee DC, Ward MF, Bruchfeld AN, Wang H, Lesser ML, Church AL, Litroff AH, Sama AE, Tracey KJ: Elevated high-mobility group box 1 levels in patients with cerebral and myocardial ischemia. Shock 2006;25:571-574.

66 Su Z, Lu H, Jiang H, Zhu H, Li Z, Zhang P, Ni P, Shen H, Xu W, Xu H: IFN-gamma-producing Th17 cells bias by HMGB1-T-bet/RUNX3 axis might contribute to progression of coronary artery atherosclerosis. Atherosclerosis 2015;243:421-428. 


\section{Cellular Physiology Cell Physiol Biochem 2018;47:1319-1337

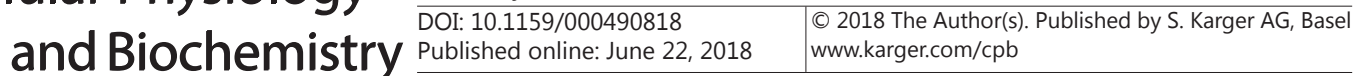

Wu et al.: Hmgb-1 in Thrombosis

67 Yamashita A, Nishihira K, Matsuura Y, Ito T, Kawahara K, Hatakeyama K, Hashiguchi T, Maruyama I, Yagi H, Matsumoto M, Fujimura Y, Kitamura K, Shibata Y, Asada Y: Paucity of CD34-positive cells and increased expression of high-mobility group box 1 in coronary thrombus with type 2 diabetes mellitus. Atherosclerosis 2012;224:511-514.

68 Haghjooy-Javanmard S, Sadeghi M, Safavi S, Gheraati M, Dana N: Prognostic value of the high-mobility group box-1 in young patients with chest pain. ARYA Atheroscler 2014;10:154-158.

69 Hu X, Jiang H, Bai Q, Zhou X, Xu C, Lu Z, Cui B, Wen H: Increased serum HMGB1 is related to the severity of coronary artery stenosis. Clin Chim Acta 2009;406:139-142.

-70 Yan XX, Lu L, Peng WH, Wang LJ, Zhang Q, Zhang RY, Chen QJ, Shen WF: Increased serum HMGB1 level is associated with coronary artery disease in nondiabetic and type 2 diabetic patients. Atherosclerosis 2009;205:544-548.

71 Andrassy M, Volz HC, Maack B, Schuessler A, Gitsioudis G, Hofmann N, Laohachewin D, Wienbrandt AR, Kaya Z, Bierhaus A, Giannitsis E, Katus HA, Korosoglou G: HMGB1 is associated with atherosclerotic plaque composition and burden in patients with stable coronary artery disease. PLoS One 2012;7:e52081.

72 Kanellakis P, Agrotis A, Kyaw TS, Koulis C, Ahrens I, Mori S, Takahashi HK, Liu K, Peter K, Nishibori M, Bobik A: High-mobility group box protein 1 neutralization reduces development of diet-induced atherosclerosis in apolipoprotein e-deficient mice. Arterioscler Thromb Vasc Biol 2011;31:313-319.

73 Jin P, Zhou Q Song S, Xu J, Zhang M, Zhu M, Kang M, Shi X, Shi J, Lu D, Li J: Elevated preoperative HMGB1 as predictor of myocardial injury post-percutaneous coronary intervention. Medicine (Baltimore) 2016;95:e5149.

74 Rath D, Geisler T, Gawaz M, Vogel S: HMGB1 Expression Level in Circulating Platelets is not Significantly Associated with Outcomes in Symptomatic Coronary Artery Disease. Cell Physiol Biochem 2017;43:16271633.

75 Kohno T, Anzai T, Naito K, Miyasho T, Okamoto M, Yokota H, Yamada S, Maekawa Y, Takahashi T, Yoshikawa T, Ishizaka A, Ogawa S: Role of high-mobility group box 1 protein in post-infarction healing process and left ventricular remodelling. Cardiovasc Res 2009;81:565-573.

76 Schulze J, Zierath D, Tanzi P, Cain K, Shibata D, Dressel A, Becker K: Severe stroke induces long-lasting alterations of high-mobility group box 1. Stroke 2013;44:246-248.

77 Tang SC, Wang YC, Li YI, Lin HC, Manzanero S, Hsieh YH, Phipps S, Hu CJ, Chiou HY, Huang YS, Yang WS, Mattson MP, Arumugam TV, Jeng JS: Functional role of soluble receptor for advanced glycation end products in stroke. Arterioscler Thromb Vasc Biol 2013;33:585-594.

78 Tsukagawa T, Katsumata R, Fujita M, Yasui K, Akhoon C, Ono K, Dohi K, Aruga T: Elevated Serum HighMobility Group Box-1 Protein Level Is Associated with Poor Functional Outcome in Ischemic Stroke. J Stroke Cerebrovasc Dis 2017.

79 Lee JH, Yoon EJ, Seo J, Kavoussi A, Chung YE, Chung SP, Park I, Kim CH, You JS: Hypothermia inhibits the propagation of acute ischemic injury by inhibiting HMGB1. Mol Brain 2016;9:81.

-80 Ye X, Chopp M, Liu X, Zacharek A, Cui X, Yan T, Roberts C, Chen J: Niaspan reduces high-mobility group box 1/receptor for advanced glycation endproducts after stroke in type-1 diabetic rats. Neuroscience 2011;190:339-345.

-81 Yang QW, Lu FL, Zhou Y, Wang L, Zhong Q, Lin S, Xiang J, Li JC, Fang CQ, Wang JZ: HMBG1 mediates ischemiareperfusion injury by TRIF-adaptor independent Toll-like receptor 4 signaling. J Cereb Blood Flow Metab 2011;31:593-605.

-82 Nakamura Y, Nakano T, Irie K, Sano K, Tanaka J, Yamashita Y, Satho T, Matsuo K, Fujioka M, Ishikura H, Mishima K: Recombinant human soluble thrombomodulin ameliorates cerebral ischemic injury through a high-mobility group box 1 inhibitory mechanism without hemorrhagic complications in mice. J Neurol Sci 2016;362:278-282.

83 Chang CY, Kao TK, Chen WY, Ou YC, Li JR, Liao SL, Raung SL, Chen CJ: Tetramethylpyrazine inhibits neutrophil activation following permanent cerebral ischemia in rats. Biochem Biophys Res Commun 2015;463:421-427.

-84 Fujioka M, Nakano T, Hayakawa K, Irie K, Akitake Y, Sakamoto Y, Mishima K, Muroi C, Yonekawa Y, Banno F, Kokame K, Miyata T, Nishio K, Okuchi K, Iwasaki K, Fujiwara M, Siesjo BK: ADAMTS13 gene deletion enhances plasma high-mobility group box1 elevation and neuroinflammation in brain ischemiareperfusion injury. Neurol Sci 2012;33:1107-1115. 


\section{Cellular Physiology Cell Physiol Biochem 2018;47:1319-1337

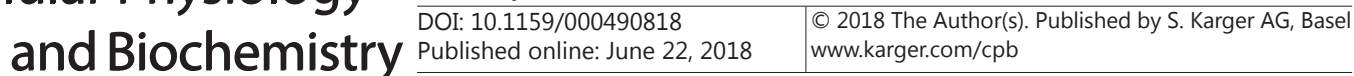

Wu et al.: Hmgb-1 in Thrombosis

85 Qiu J, Nishimura M, Wang Y, Sims JR, Qiu S, Savitz SI, Salomone S, Moskowitz MA: Early release of HMGB-1 from neurons after the onset of brain ischemia. J Cereb Blood Flow Metab 2008;28:927-938.

-86 Kim SW, Jin Y, Shin JH, Kim ID, Lee HK, Park S, Han PL, Lee JK: Glycyrrhizic acid affords robust neuroprotection in the postischemic brain via anti-inflammatory effect by inhibiting HMGB1 phosphorylation and secretion. Neurobiol Dis 2012;46:147-156.

87 Zhang J, Takahashi HK, Liu K, Wake H, Liu R, Maruo T, Date I, Yoshino T, Ohtsuka A, Mori S, Nishibori M: Anti-high mobility group box-1 monoclonal antibody protects the blood-brain barrier from ischemiainduced disruption in rats. Stroke 2011;42:1420-1428.

-88 Liu K, Mori S, Takahashi HK, Tomono Y, Wake H, Kanke T, Sato Y, Hiraga N, Adachi N, Yoshino T, Nishibori M: Anti-high mobility group box 1 monoclonal antibody ameliorates brain infarction induced by transient ischemia in rats. FASEB J 2007;21:3904-3916.

-89 Kim ID, Shin JH, Kim SW, Choi S, Ahn J, Han PL, Park JS, Lee JK: Intranasal delivery of HMGB1 siRNA confers target gene knockdown and robust neuroprotection in the postischemic brain. Mol Ther 2012;20:829-839.

90 Xiong X, Gu L, Wang Y, Luo Y, Zhang H, Lee J, Krams S, Zhu S, Zhao H: Glycyrrhizin protects against focal cerebral ischemia via inhibition of T cell activity and HMGB1-mediated mechanisms. J Neuroinflammation 2016;13:241.

91 Umahara T, Uchihara T, Hirokawa K, Hirao K, Shimizu S, Hashimoto T, Terasi H, Hanyu H: Time-dependent and lesion-dependent HMGB1-selective localization in brains of patients with cerebrovascular diseases. Histol Histopathol 2017:11914.

-92 Oozawa S, Sano S, Nishibori M: Usefulness of high mobility group box 1 protein as a plasma biomarker in patient with peripheral artery disease. Acta Med Okayama 2014;68:157-162.

93 Giovannini S, Tinelli G, Biscetti F, Straface G, Angelini F, Pitocco D, Mucci L, Landolfi R, Flex A: Serum high mobility group box-1 and osteoprotegerin levels are associated with peripheral arterial disease and critical limb ischemia in type 2 diabetic subjects. Cardiovasc Diabetol 2017;16:99.

-94 Tsao CF, Huang WT, Liu TT, Wang PW, Liou CW, Lin TK, Hsieh CJ, Weng SW: Expression of high-mobility group box protein 1 in diabetic foot atherogenesis. Genet Mol Res 2015;14:4521-4531.

-95 Huang SC, Wang M, Wu WB, Wang R, Cui J, Li W, Li ZL, Li W, Wang SM: Mir-22-3p Inhibits Arterial Smooth Muscle Cell Proliferation and Migration and Neointimal Hyperplasia by Targeting HMGB1 in Arteriosclerosis Obliterans. Cell Physiol Biochem 2017;42:2492-2506.

-96 Wang M, Mei H, Kou H, Deng J, Wang H, Guo T, Hu Y: Role of plasma high mobility group box-1 in disseminated intravascular coagulation with leukemia. Thromb Res 2015.

-97 Eskici ZM, Acikgoz S, Piskin N, Mungan G, Can M, Guven B, Kokturk F: High mobility group B1 levels in sepsis and Disseminated Intravascular Coagulation. Acta Biochim Pol 2012;59:561-566.

-98 Hatada T, Wada H, Nobori T, Okabayashi K, Maruyama K, Abe Y, Uemoto S, Yamada S, Maruyama I: Plasma concentrations and importance of High Mobility Group Box protein in the prognosis of organ failure in patients with disseminated intravascular coagulation. Thromb Haemost 2005;94:975-979.

-99 Inoue Y, Saito T, Ogawa K, Nishio Y, Kosugi S, Suzuki Y, Sakai H, Kato M, Takahashi M, Miura I: Role of serum high mobility group box 1 in hematological malignancies complicated with systemic inflammatory response syndrome and effect of recombinant thrombomodulin. Leuk Lymphoma 2013;54:1953-1958.

100 Nomura S, Fujita S, Ozasa R, Nakanishi T, Miyaji M, Mori S, Ito T, Ishii K: The correlation between platelet activation markers and HMGB1 in patients with disseminated intravascular coagulation and hematologic malignancy. Platelets 2011;22:396-397.

101 Gu JJ, Chen JB, Zhang JH, Zhang H, Wang SS: Recombinant human soluble thrombomodulin protects against brain injury in a CVST rat model, via downregulation of the HMGB1-RAGE axis. Mol Med Rep 2016

-102 Rouhiainen A, Imai S, Rauvala H, Parkkinen J: Occurrence of amphoterin (HMG1) as an endogenous protein of human platelets that is exported to the cell surface upon platelet activation. Thromb Haemost 2000;84:1087-1094.

103 Yang X, Wang H, Zhang M, Liu J, Lv B, Chen F: HMGB1: a novel protein that induced platelets active and aggregation via Toll-like receptor-4, NF-kappaB and cGMP dependent mechanisms. Diagn Pathol $2015 ; 10: 134$.

104 Goetzl EJ, Goetzl L, Karliner JS, Tang N, Pulliam L: Human plasma platelet-derived exosomes: effects of aspirin. FASEB J 2016;30:2058-2063. 


\section{Cellular Physiology Cell Physiol Biochem 2018;47:1319-1337 \begin{tabular}{l|l} 
DOI: 10.1159/000490818 & and Biochemistry \\
Published online: June 22, 2018 & $\begin{array}{l}\text { O 2018 The Author(s). Published by S. Karger AG, Basel } \\
\text { www.karger.com/cpb }\end{array}$
\end{tabular}}

Wu et al.: Hmgb-1 in Thrombosis

105 Vogel S, Chatterjee M, Metzger K, Borst O, Geisler T, Seizer P, Muller I, Mack A, Schumann S, Buhring HJ, Lang F, Sorg RV, Langer H, Gawaz M: Activated platelets interfere with recruitment of mesenchymal stem cells to apoptotic cardiac cells via high mobility group box 1/Toll-like receptor 4-mediated downregulation of hepatocyte growth factor receptor MET. J Biol Chem 2014;289:11068-11082.

106 Maugeri N, Campana L, Gavina M, Covino C, De Metrio M, Panciroli C, Maiuri L, Maseri A, D’Angelo A, Bianchi ME, Rovere-Querini P, Manfredi AA: Activated platelets present high mobility group box 1 to neutrophils, inducing autophagy and promoting the extrusion of neutrophil extracellular traps. J Thromb Haemost 2014;12:2074-2088.

107 Ito T, Kawahara K, Nakamura T, Yamada S, Nakamura T, Abeyama K, Hashiguchi T, Maruyama I: Highmobility group box 1 protein promotes development of microvascular thrombosis in rats. J Thromb Haemost 2007;5:109-116.

108 Zhang G, Han J, Welch EJ, Ye RD, Voyno-Yasenetskaya TA, Malik AB, Du X, Li Z: Lipopolysaccharide stimulates platelet secretion and potentiates platelet aggregation via TLR4/MyD88 and the cGMPdependent protein kinase pathway. J Immunol 2009;182:7997-8004.

109 Yu LX, Yan L, Yang W, Wu FQ, Ling Y, Chen SZ, Tang L, Tan YX, Cao D, Wu MC, Yan HX, Wang HY: Platelets promote tumour metastasis via interaction between TLR4 and tumour cell-released high-mobility group box1 protein. Nat Commun 2014;5:5256.

110 Tsai JC, Lin YW, Huang CY, Lin FY, Tsai CS: Calpain activity and Toll-like receptor 4 expression in platelet regulate haemostatic situation in patients undergoing cardiac surgery and coagulation in mice. Mediators Inflamm 2014;2014:484510.

111 Gurses KM, Kocyigit D, Yalcin MU, Canpinar H, Oto MA, Ozer N, Tokgozoglu L, Guc D, Aytemir K: Enhanced Platelet Toll-like Receptor 2 and 4 Expression in Acute Coronary Syndrome and Stable Angina Pectoris. Am J Cardiol 2015;116:1666-1671.

112 Rivadeneyra L, Carestia A, Etulain J, Pozner RG, Fondevila C, Negrotto S, Schattner M: Regulation of platelet responses triggered by Toll-like receptor 2 and 4 ligands is another non-genomic role of nuclear factorkappaB. Thromb Res 2014;133:235-243.

113 Ward JR, Bingle L, Judge HM, Brown SB, Storey RF, Whyte MK, Dower SK, Buttle DJ, Sabroe I: Agonists of toll-like receptor (TLR)2 and TLR4 are unable to modulate platelet activation by adenosine diphosphate and platelet activating factor. Thromb Haemost 2005;94:831-838.

114 Panigrahi S, Ma Y, Hong L, Gao D, West XZ, Salomon RG, Byzova TV, Podrez EA: Engagement of platelet tolllike receptor 9 by novel endogenous ligands promotes platelet hyperreactivity and thrombosis. Circ Res 2013;112:103-112.

115 Laursen TL, Stoy S, Deleuran B, Vilstrup H, Gronbaek H, Sandahl TD: The damage-associated molecular pattern HMGB1 is elevated in human alcoholic hepatitis, but does not seem to be a primary driver of inflammation. APMIS 2016;124:741-747.

116 Zhang Y, Karki R, Igwe OJ: Toll-like receptor 4 signaling: A common pathway for interactions between prooxidants and extracellular disulfide high mobility group box 1 (HMGB1) protein-coupled activation. Biochem Pharmacol 2015;98:132-143.

117 Huebener P, Pradere JP, Hernandez C, Gwak GY, Caviglia JM, Mu X, Loike JD, Jenkins RE, Antoine DJ, Schwabe RF: The HMGB1/RAGE axis triggers neutrophil-mediated injury amplification following necrosis. J Clin Invest 2015;125:539-550.

118 Huang H, Tohme S, Al-Khafaji AB, Tai S, Loughran P, Chen L, Wang S, Kim J, Billiar T, Wang Y, Tsung A: Damage-associated molecular pattern-activated neutrophil extracellular trap exacerbates sterile inflammatory liver injury. Hepatology 2015;62:600-614.

119 Xu L, Zhao K, Shen X, Fan XX, Ding K, Liu RM, Wang F: Blockade of Extracellular High-Mobility Group Box 1 Attenuates Systemic Inflammation and Coagulation Abnormalities in Rats with Acute Traumatic Coagulopathy. Med Sci Monit 2016;22:2561-2570.

120 Fuchs TA, Brill A, Wagner DD: Neutrophil extracellular trap (NET) impact on deep vein thrombosis. Arterioscler Thromb Vasc Biol 2012;32:1777-1783.

121 Martinod K, Wagner DD: Thrombosis: tangled up in NETs. Blood 2014;123:2768-2776.

122 Meng H, Yalavarthi S, Kanthi Y, Mazza LF, Elfline MA, Luke CE, Pinsky DJ, Henke PK, Knight JS: In vivo role of neutrophil extracellular traps in antiphospholipid antibody-mediated venous thrombosis. Arthritis Rheumatol 2016. 
123 von Bruhl ML, Stark K, Steinhart A, Chandraratne S, Konrad I, Lorenz M, Khandoga A, Tirniceriu A, Coletti R, Kollnberger M, Byrne RA, Laitinen I, Walch A, Brill A, Pfeiler S, Manukyan D, Braun S, Lange P, Riegger J, Ware J, Eckart A, Haidari S, Rudelius M, Schulz C, Echtler K, Brinkmann V, Schwaiger M, Preissner KT, Wagner DD, Mackman N, Engelmann B, Massberg S: Monocytes, neutrophils, and platelets cooperate to initiate and propagate venous thrombosis in mice in vivo. J Exp Med 2012;209:819-835.

124 Martinod K, Demers M, Fuchs TA, Wong SL, Brill A, Gallant M, Hu J, Wang Y, Wagner DD: Neutrophil histone modification by peptidylarginine deiminase 4 is critical for deep vein thrombosis in mice. Proc Natl Acad Sci U S A 2013;110:8674-8679.

125 Delabranche X, Stiel L, Severac F, Galoisy AC, Mauvieux L, Zobairi F, Lavigne T, Toti F, Angles-Cano E, Meziani F, Boisrame-Helms J: Evidence of NETosis in Septic Shock-induced Disseminated Intravascular Coagulation. Shock 2016.

-126 Riegger J, Byrne RA, Joner M, Chandraratne S, Gershlick AH, Ten Berg JM, Adriaenssens T, Guagliumi G, Godschalk TC, Neumann FJ, Trenk D, Feldman LJ, Steg PG, Desmet W, Alfonso F, Goodall AH, Wojdyla R, Dudek D, Philippi V, Opinaldo S, Titova A, Malik N, Cotton J, Jhagroe DA, Heestermans AA, Sinnaeve P, Vermeersch P, Valina C, Schulz C, Kastrati A, Massberg S, Prevention of Late Stent Thrombosis by an Interdisciplinary Global European Effort I: Histopathological evaluation of thrombus in patients presenting with stent thrombosis. A multicenter European study: a report of the prevention of late stent thrombosis by an interdisciplinary global European effort consortium. Eur Heart J 2016;37:1538-1549.

127 Stakos DA, Kambas K, Konstantinidis T, Mitroulis I, Apostolidou E, Arelaki S, Tsironidou V, Giatromanolaki A, Skendros P, Konstantinides S, Ritis K: Expression of functional tissue factor by neutrophil extracellular traps in culprit artery of acute myocardial infarction. Eur Heart J 2015;36:1405-1414.

128 Mangold A, Alias S, Scherz T, Hofbauer T, Jakowitsch J, Panzenbock A, Simon D, Laimer D, Bangert C, Kammerlander A, Mascherbauer J, Winter MP, Distelmaier K, Adlbrecht C, Preissner KT, Lang IM: Coronary neutrophil extracellular trap burden and deoxyribonuclease activity in ST-elevation acute coronary syndrome are predictors of ST-segment resolution and infarct size. Circ Res 2015;116:1182-1192.

129 de Boer OJ, Li X, Teeling P, Mackaay C, Ploegmakers HJ, van der Loos CM, Daemen MJ, de Winter RJ, van der Wal AC: Neutrophils, neutrophil extracellular traps and interleukin-17 associate with the organisation of thrombi in acute myocardial infarction. Thromb Haemost 2013;109:290-297.

130 Shahidi M: Thrombosis and von Willebrand Factor. Adv Exp Med Biol 2016.

131 Semeraro F, Ammollo CT, Morrissey JH, Dale GL, Friese P, Esmon NL, Esmon CT: Extracellular histones promote thrombin generation through platelet-dependent mechanisms: involvement of platelet TLR2 and TLR4. Blood 2011;118:1952-1961.

132 Si-Tahar M, Pidard D, Balloy V, Moniatte M, Kieffer N, Van Dorsselaer A, Chignard M: Human neutrophil elastase proteolytically activates the platelet integrin alphaIIbbeta3 through cleavage of the carboxyl terminus of the alphaIIb subunit heavy chain. Involvement in the potentiation of platelet aggregation. J Biol Chem 1997;272:11636-11647.

133 Yang S, Qi H, Kan K, Quan C, Xie H, Guo X, Zhang L: Neutrophil Extracellular Traps Promote Hypercoagulability in Patients with Sepsis. Shock 2016.

134 Gould TJ, Vu TT, Swystun LL, Dwivedi DJ, Mai SH, Weitz JI, Liaw PC: Neutrophil extracellular traps promote thrombin generation through platelet-dependent and platelet-independent mechanisms. Arterioscler Thromb Vasc Biol 2014;34:1977-1984.

135 Massberg S, Grahl L, von Bruehl ML, Manukyan D, Pfeiler S, Goosmann C, Brinkmann V, Lorenz M, Bidzhekov K, Khandagale AB, Konrad I, Kennerknecht E, Reges K, Holdenrieder S, Braun S, Reinhardt C, Spannagl M, Preissner KT, Engelmann B: Reciprocal coupling of coagulation and innate immunity via neutrophil serine proteases. Nat Med 2010;16:887-896.

136 Maugeri N, Rovere-Querini P, Baldini M, Baldissera E, Sabbadini MG, Bianchi ME, Manfredi AA: Oxidative stress elicits platelet/leukocyte inflammatory interactions via HMGB1: a candidate for microvessel injury in sytemic sclerosis. Antioxid Redox Signal 2014;20:1060-1074.

137 Ma YH, Ma TT, Wang C, Wang H, Chang DY, Chen M, Zhao MH: High-mobility group box 1 potentiates antineutrophil cytoplasmic antibody-inducing neutrophil extracellular traps formation. Arthritis Res Ther 2016;18:2.

138 Xiang M, Yin L, Li Y, Xiao G, Vodovotz Y, Billiar TR, Wilson MA, Fan J: Hemorrhagic shock activates lung endothelial reduced nicotinamide adenine dinucleotide phosphate (NADPH) oxidase via neutrophil NADPH oxidase. Am J Respir Cell Mol Biol 2011;44:333-340. 


\section{Cellular Physiology Cell Physiol Biochem 2018;47:1319-1337

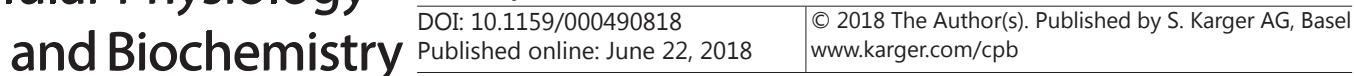

Wu et al.: Hmgb-1 in Thrombosis

139 Fan J, Li Y, Levy RM, Fan JJ, Hackam DJ, Vodovotz Y, Yang H, Tracey KJ, Billiar TR, Wilson MA: Hemorrhagic shock induces NAD(P)H oxidase activation in neutrophils: role of HMGB1-TLR4 signaling. J Immunol 2007;178:6573-6580.

140 Lv B, Wang H, Tang Y, Fan Z, Xiao X, Chen F: High-mobility group box 1 protein induces tissue factor expression in vascular endothelial cells via activation of NF-kappaB and Egr-1. Thromb Haemost 2009;102:352-359.

141 Winckers K, ten Cate H, Hackeng TM: The role of tissue factor pathway inhibitor in atherosclerosis and arterial thrombosis. Blood Rev 2013;27:119-132.

142 Kules J, Gotic J, Mrljak V, Baric Rafaj R: Blood markers of fibrinolysis and endothelial activation in canine babesiosis. BMC Vet Res 2017;13:82.

143 Bongoni AK, Klymiuk N, Wolf E, Ayares D, Rieben R, Cowan PJ: Transgenic Expression of Human Thrombomodulin Inhibits HMGB1-Induced Porcine Aortic Endothelial Cell Activation. Transplantation 2016;100:1871-1879.

144 Loscalzo J: Nitric oxide insufficiency, platelet activation, and arterial thrombosis. Circ Res 2001;88:756762.

145 Wu KM, Lin CC, Chiu CH, Liaw SF: Effect of treatment by nasal continuous positive airway pressure on serum high mobility group box-1 protein in obstructive sleep apnea. Chest 2010;137:303-309.

146 Zhang Y, Li X, Pitzer AL, Chen Y, Wang L, Li PL: Coronary endothelial dysfunction induced by nucleotide oligomerization domain-like receptor protein with pyrin domain containing 3 inflammasome activation during hypercholesterolemia: beyond inflammation. Antioxid Redox Signal 2015;22:1084-1096.

-147 Tang ST, Wang F, Shao M, Wang Y, Zhu HQ: MicroRNA-126 suppresses inflammation in endothelial cells under hyperglycemic condition by targeting HMGB1 Vascul Pharmacol 2017;88:48-55.

148 Cai W, Duan XM, Liu Y, Yu J, Tang YL, Liu ZL, Jiang S, Zhang CP, Liu JY, Xu JX: Uric Acid Induces Endothelial Dysfunction by Activating the HMGB1/RAGE Signaling Pathway. Biomed Res Int 2017;2017:4391920.

149 Gong G, Xiang L, Yuan L, Hu L, Wu W, Cai L, Yin L, Dong H: Protective effect of glycyrrhizin, a direct HMGB1 inhibitor, on focal cerebral ischemia/reperfusion-induced inflammation, oxidative stress, and apoptosis in rats. PLoS One 2014;9:e89450.

150 Huang J, Liu B, Yang C, Chen H, Eunice D, Yuan Z: Acute hyperglycemia worsens ischemic stroke-induced brain damage via high mobility group box-1 in rats. Brain Res 2013;1535:148-155.

151 Shin JH, Lee HK, Lee HB, Jin Y, Lee JK: Ethyl pyruvate inhibits HMGB1 phosphorylation and secretion in activated microglia and in the postischemic brain. Neurosci Lett 2014;558:159-163.

152 Xiao H, Liu H, Hou C, Liu Y, Yu Q: Effects of Ethyl Pyruvate in Preventing the Development of Diet-induced Atherosclerosis by Blocking the HMGB1 Expression in ApoE-Deficient Mice. J Cardiovasc Pharmacol 2016;67:299-304.

153 Wang JG, Bondy SC, Zhou L, Yang FZ, Ding ZG, Hu Y, Tian Y, Wen PY, Luo H, Wang F, Li WW, Zhou J: Protective effect of Tanshinone IIA against infarct size and increased HMGB1, NFkappaB, GFAP and apoptosis consequent to transient middle cerebral artery occlusion. Neurochem Res 2014;39:295-304.

154 Pan Y, Qian JX, Lu SQ Chen JW, Zhao XD, Jiang Y, Wang LH, Zhang GX: Protective effects of tanshinone IIA sodium sulfonate on ischemia-reperfusion-induced myocardial injury in rats. Iran J Basic Med Sci 2017;20:308-315.

155 Haraba R, Suica VI, Uyy E, Ivan L, Antohe F: Hyperlipidemia stimulates the extracellular release of the nuclear high mobility group box 1 protein. Cell Tissue Res 2011;346:361-368.

156 Zhang T, Yang S, Du J: Protective Effects of Berberine on Isoproterenol-Induced Acute Myocardial Ischemia in Rats through Regulating HMGB1-TLR4 Axis. Evid Based Complement Alternat Med 2014;2014:849783.

157 Vuohelainen V, Hamalainen M, Paavonen T, Karlsson S, Moilanen E, Mennander A: Inhibition of monoamine oxidase A increases recovery after experimental cardiac arrest. Interact Cardiovasc Thorac Surg 2015;21:441-449.

158 Hu X, Zhou X, He B, Xu C, Wu L, Cui B, Wen H, Lu Z, Jiang H: Minocycline protects against myocardial ischemia and reperfusion injury by inhibiting high mobility group box 1 protein in rats. Eur J Pharmacol 2010;638:84-89.

159 Xiong XX, Gu LJ, Shen J, Kang XH, Zheng YY, Yue SB, Zhu SM: Probenecid protects against transient focal cerebral ischemic injury by inhibiting HMGB1 release and attenuating AQP4 expression in mice. Neurochem Res 2014;39:216-224. 


\section{Cellular Physiology Cell Physiol Biochem 2018;47:1319-1337

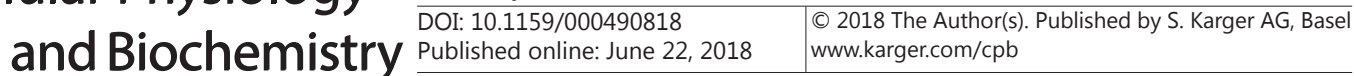

Wu et al.: Hmgb-1 in Thrombosis

160 Zheng C, Liu C, Wang W, Tang G, Dong L, Zhou J, Zhong Z: Ethanol extracts from Portulaca oleracea L. attenuated ischemia/reperfusion induced rat neural injury through inhibition of HMGB1 induced inflammation. Am J Transl Res 2016;8:5016-5024.

161 Xin Q, Cheng B, Pan Y, Liu H, Yang C, Chen J, Bai B: Neuroprotective effects of apelin-13 on experimental ischemic stroke through suppression of inflammation. Peptides 2015;63:55-62.

162 Li X, Hu X, Wang J, Xu W, Yi C, Ma R, Jiang H: Short-Term Hesperidin Pretreatment Attenuates Rat Myocardial Ischemia/Reperfusion Injury by Inhibiting High Mobility Group Box 1 Protein Expression via the PI3K/Akt Pathway. Cell Physiol Biochem 2016;39:1850-1862.

163 Filipek A, Czerwinska ME, Kiss AK, Polanski JA, Naruszewicz M: Oleacein may inhibit destabilization of carotid plaques from hypertensive patients. Impact on high mobility group protein-1. Phytomedicine 2017;32:68-73.

$164 \mathrm{Hu}$ X, Ma R, Lu J, Zhang K, Xu W, Jiang H, Da Y: IL-23 Promotes Myocardial I/R Injury by Increasing the Inflammatory Responses and Oxidative Stress Reactions. Cell Physiol Biochem 2016;38:2163-2172.

165 Choi HW, Tian M, Song F, Venereau E, Preti A, Park SW, Hamilton K, Swapna GV, Manohar M, Moreau M, Agresti A, Gorzanelli A, De Marchis F, Wang H, Antonyak M, Micikas RJ, Gentile DR, Cerione RA, Schroeder FC, Montelione GT, Bianchi ME, Klessig DF: Aspirin's Active Metabolite Salicylic Acid Targets High Mobility Group Box 1 to Modulate Inflammatory Responses. Mol Med 2015;21:526-535.

166 Klessig DF: Newly Identified Targets of Aspirin and Its Primary Metabolite, Salicylic Acid. DNA Cell Biol 2016;35:163-166.

167 Hagiwara S, Iwasaka H, Hasegawa A, Oyama M, Imatomi R, Uchida T, Noguchi T: Adenosine diphosphate receptor antagonist clopidogrel sulfate attenuates LPS-induced systemic inflammation in a rat model. Shock 2011;35:289-292.

168 Chang KC: Cilostazol inhibits HMGB1 release in LPS-activated RAW 264.7 cells and increases the survival of septic mice. Thromb Res 2015;136:456-464.

169 Ning F, Wang X, Shang L, Wang T, Lv C, Qi Z, Wu D: Low molecular weight heparin may prevent acute lung injury induced by sepsis in rats. Gene 2015;557:88-91.

170 Luan ZG, Naranpurev M, Ma XC: Treatment of low molecular weight heparin inhibits systemic inflammation and prevents endotoxin-induced acute lung injury in rats. Inflammation 2014;37:924-932.

171 Lu X, Zhao L, Xu YH: Low molecular weight heparin prevents CLP-induced acute lung injury in rats by antiinflammatory coagulation. Bosn J Basic Med Sci 2013;13:50-56.

172 Manfredi AA, Rovere-Querini P, D’Angelo A, Maugeri N: Low molecular weight heparins prevent the induction of autophagy of activated neutrophils and the formation of neutrophil extracellular traps. Pharmacol Res 2017.

173 Rao NV, Argyle B, Xu X, Reynolds PR, Walenga JM, Prechel M, Prestwich GD, MacArthur RB, Walters BB, Hoidal JR, Kennedy TP: Low anticoagulant heparin targets multiple sites of inflammation, suppresses heparin-induced thrombocytopenia, and inhibits interaction of RAGE with its ligands. Am J Physiol Cell Physiol 2010;299:C97-110.

174 Zheng S, Kummarapurugu AB, Afosah DK, Sankaranarayanan NV, Boothello RS, Desai UR, Kennedy T, Voynow JA: 2-0, 3-0 Desulfated Heparin Blocks High Mobility Group Box 1 Release by Inhibition of p300 Acetyltransferase Activity. Am J Respir Cell Mol Biol 2017;56:90-98.

175 Iba T, Aihara K, Watanabe S, Yanagawa Y, Takemoto M, Yamada A, Yang D: Recombinant thrombomodulin improves the visceral microcirculation by attenuating the leukocyte-endothelial interaction in a rat LPS model. Thromb Res 2013;131:295-299.

176 Ito T, Kawahara K, Okamoto K, Yamada S, Yasuda M, Imaizumi H, Nawa Y, Meng X, Shrestha B, Hashiguchi T, Maruyama I: Proteolytic cleavage of high mobility group box 1 protein by thrombin-thrombomodulin complexes. Arterioscler Thromb Vasc Biol 2008;28:1825-1830. 